\title{
Dois anos na vida de uma revista científica: Um olhar para o futuro
}

\author{
Two years in a journal's life: Looking into the future
}

\section{J. Vasconcelos-Raposo}

Director da Revista Motricidade - Universidade de Trás-os-Montes e Alto Douro

Com o presente número fechamos o primeiro ciclo de dois anos de gestão e coordenação da revista e da equipa Motricidade. Chegamos aonde chegamos, porque fomos um todo. Foram dois anos em que o esforço desta equipa se salda de forma positiva em muitos aspectos. Em primeiro lugar, hoje somos mais próximos e mais amigos uns dos outros. Depois, poderíamos elencar múltiplos aspectos, mas para os propósitos deste editorial escolhemos destacar a internacionalização da Motricidade e, por último, apontar um possível caminho, para um futuro diferente.

Presentemente, menos de $18 \%$ dos nossos visitantes têm IPs de Portugal, sendo cerca de $65 \%$ oriundos dos países da América do Sul e Espanha, onde, por razões evidentes a maioria são do Brasil. Não podemos deixar de destacar o aumento crescente das visitas e downloads que têm origem em países como Estados Unidos de América, Reino Unido, Austrália, China, Alemanha, Irão, Dinamarca, Itália, Montenegro, Taiwan, entre outros. Neste balanço que fazemos da recuperação da Motricidade, realizada por esta equipa, constatamos que o número de países representados nos IPs, registados pelos nossos serviços de apoio, ultrapassa as quatro dezenas. Esta é uma constatação que nos obriga a repensar a dimensão da revista e ter que, desde já, começar a delinear estratégias de acção que nos possibilitem dar uma resposta mais adequada aos que nos procuram.

A dimensão da internacionalização não deve ser aferida apenas pelo número de países que estão representados na recolha de estatísticas que fazemos. É da maior importância termos a noção clara que um dos aspectos a ter em conta é a presença da Revista Motricidade nas bibliografias de outras revistas. Ao contrário de outros periódicos de referência, quem constrói o seu curriculum publicando os seus trabalhos na Motricidade, não tem de ter um número mínimo de citações da revista, para que os seus trabalhos sejam aceites. É gratificante para esta equipa editorial, poder afirmar, categoricamente, a sua imunidade às práticas de "Gate Keeping".

Hoje, é mais difícil publicar na Motricidade do que quando esta se relançou em 2009. Temos um número mais acentuado de artigos por onde escolher. Mas este é um facto que se apresenta com uma "faca de dois gumes". Estamos satisfeitos por ter maior escolha, mas concomitantemente este é um motivo de angústia, na medida em que de alguma forma sentimo-nos a não satisfazer as eventuais expectativas daqueles que desejam beneficiar do serviço que prestamos. Numa análise simplista dir-se-ia que a solução é aumentar o número de artigos publicados por volume, mas infelizmente a realidade é bem diferente e exige outro tipo de soluções.

Quando olhamos ao caminho percorrido de Outubro de 2009 até ao mês de Setembro de 2010, é surpreendentemente gratificante constatar o número de visitas que nos fizeram, em média mais de 21000 por mês, o que nos permite afirmar que ultrapassamos, de forma clara, as $\mathbf{2 5 0}$ mil visitas por ano.

$\mathrm{Na}$ análise que fazemos, relativamente a um período de actividade, muitos são os aspectos que podem ser referidos para 


\section{2 | J. Vasconcelos-Raposo}

aconchegar os nossos egos. Porém, de acordo com a filosofia de trabalho que impera na equipa editorial da Motricidade, o sucesso até agora conseguido é tão só a confirmação que o trilho, colectivamente definido, está provavelmente correcto, e por isso carece de reconfirmação, o que só será possível com a obtenção de sucesso nas iniciativas que emergirem do alargamento das nossas actividades. Somar visitantes, aumentar o número de submissões com qualidade é algo a continuar, para que possamos garantir o progresso. Mas, enquanto equipa, desejamos mais do que progresso, queremos ser bem sucedidos e por isso procuraremos ser criativos e tomar as decisões que se nos apresentarem fundamentais para atingirmos novos patamares. Esta é a altura de olharmos, criticamente, ao que foi feito e tomar medidas para assegurar um melhor futuro. Assim, a quem nos ajudou a crescer, estamos gratos, a quem andou à nossa "boleia", abriremos a porta para continuarem o seu caminho, mas sem a nossa companhia. Este é, também, o momento para reconstruir o corpo editorial da revista procurando envolver novos elementos e que tenham a ambição de ser agentes activos no engrandecimento da comunidade científica, através da sua generosidade para com o outro, doando-lhes algum do seu tempo. Isto é algo que é fácil fazer, pelos mais nobres Homens e Mulheres da Ciência, mas difícil para aqueles que vêem na prática científica pouco mais que um mero exercício de acumulação de linhas no seu CV, mesmo que essas sejam o espelho de uma prática mecanizada e sem efectivamente contribuir para o enriquecimento do conhecimento científico.

Porque a nossa equipa é constituída por "Homens e Mulheres" da Ciência, estamos conscientes que a renovação de ideias se faz com novas pessoas e com elas virão novos métodos. Porque nos percepcionamos como elementos activos de uma comunidade científica, gostaríamos de receber contributos de todos aqueles que desejem impor-se ao rigor e à disciplina necessárias para implementar projectos que visem engrandecer a prática científica em geral, mas de uma forma particular a disseminação do conhecimento, tal como ela toma forma no processo editorial nas revistas científicas.

A todos os que nos confiaram os seus trabalhos, a equipa da Motricidade diz OBRIGADO. 